\title{
Effective elimination of adult B-lineage acute Iymphoblastic leukemia by disulfiram/copper complex in vitro and in vivo in patient-derived xenograft models
}

\author{
Manman Deng ${ }^{1,3, *}$, Zhiwu Jiang ${ }^{2, *}$, Yin $\mathrm{Li}^{3, *}$, Yong Zhou ${ }^{1}$, Jie $\mathrm{Li}^{3}$, Xiangmeng Wang ${ }^{3}$, \\ Yao Yao ${ }^{4}$, Weiguang Wang ${ }^{5}$, Peng $\mathrm{Li}^{2}$, Bing $\mathrm{Xu}^{1}$ \\ ${ }^{1}$ Department of Hematology, The First Affiliated Hospital of Xiamen University, Xiamen, China \\ ${ }^{2}$ Key Laboratory of Regenerative Biology, Southern China Institute for Stem Cell Biology and Regenerative Medicine, \\ Guangzhou Institutes of Biomedicine and Health, Chinese Academy of Sciences, Guangzhou, China \\ ${ }^{3}$ Department of Hematology, Nanfang Hospital, Southern Medical University, Guangzhou, China \\ ${ }^{4}$ Drug Discovery Pipeline, Guangzhou Institutes of Biomedicine and Health, Chinese Academy of Sciences, Guangzhou, China \\ ${ }^{5}$ Research Institute for Healthcare Science, Faculty of Science and Engineering, University of Wolverhampton, Wolverhampton, UK \\ *These authors have contributed equally to this work
}

Correspondence to: Bing XU, e-mail: xubingzhangjian@126.com

Peng Li, e-mail: li_peng@gibh.ac.cn

Weiguang Wang, e-mail: w.wang2@wlv.ac.uk

Keywords: disulfiram, copper, adult B-cell acute lymphoblastic leukemia, pl6 deletion, patient-derived xenograft

Received: January 6, 2016

Accepted: April 28, 2016

Published: May 17, 2016

\section{ABSTRACT}

Disulfiram (DS), a clinically used drug to control alcoholism, has displayed promising anti-cancer activity against a wide range of tumors. Here, we demonstrated that DS/copper $(\mathrm{Cu})$ complex effectively eliminated adult B-ALL cells in vitro and in vivo in patient-derived xenograft (PDX) humanized mouse models, reflected by inhibition of cell proliferation, induction of apoptosis, suppression of colony formation, and reduction of PDX tumor growth, while sparing normal peripheral blood mononuclear cells. Mechanistically, these events were associated with disruption of mitochondrial membrane potential and down-regulation of the anti-apoptotic proteins Bcl-2 and Bcl-xL. Further analysis on B-ALL patients' clinical characteristics revealed that the ex vivo efficacy of DS/Cu in primary samples was significantly correlated to p16 gene deletion and peripheral blood WBC counts at diagnosis, while age, LDH level, extramedullary infiltration, status post intensive induction therapy, immune phenotype, risk category, and Ph chromosome had no effect. Together, these findings indicate that disulfiram, particularly when administrated in combination with copper, might represent a potential repurposing agent for treatment of adult B-ALL patients, including those clinically characterized by one or more adverse prognostic factors.

\section{INTRODUCTION}

Acute lymphoblastic leukaemia (ALL) is a clinically and biologically heterogeneous disorder $[1,2]$. Despite the introduction of the first-line therapy, including highdose multi-agent combination chemotherapy (increasingly inspired to pediatric principles), hematopoietic stem cell transplantation, and new targeted therapy, which has significantly improved overall survival rate (approximately $85 \%$ ) of pediatric ALL patients, only about $30-40 \%$ of adults with ALL achieve long-term disease-free survival
(DFS) [3-5]. Among others, severe adverse events that threaten the lives of adult, especially elderly, patients with ALL represent the major hindrances to the highdose multi-agent combination chemotherapy regimens. Therefore, new therapeutic approaches with high efficacy but low toxicity are urgently needed to treat adults with ALL, in order to improve their long-term DFS as well as overall survival.

Disulfiram (DS), a member of the dithiocarbamate family, is an FDA-approved drug that has been clinically used as an alcohol-abuse deterrent for more than six 
decades $[6,7]$. In contrast to conventional chemotherapy agents, it exhibits low toxicity, while easily available and inexpensive. DS, as a strong metal-ion chelating agent, interacts with copper $(\mathrm{Cu})$ to form the $\mathrm{Ds} / \mathrm{Cu}$ complex with enhanced anti-tumor activity [8-10]. Recently, several studies have demonstrated that DS is highly effective against various types of solid tumors such as breast cancer [11-13], melanoma [9, 14, 15], and prostate cancer [16], as well as hematological malignancies, including ALL [17-19].

Apoptosis, known as type I programmed cell death, plays a critical role in development and homeostasis of organisms [20,21]. There are two major apoptotic signaling cascades, the mitochondria-mediated intrinsic pathway and the death receptor-mediated extrinsic pathway. The former is often considered as the classic apoptotic pathway, which is initiated with mitochondrial injury (e.g., loss of mitochondrial membrane potential), resulting in mitochondrial outer membrane permeabilization (MOMP) and thus release of cytochrome $\mathrm{c}$ from mitochondria to cytoplasm where it forms apoptosome with Apaf-1 to cleave/activate caspase 9 , followed by cleavage/activation of the executioner caspase-3, ultimately inducing apoptosis [22, 23, 24].

Currently, it remains to be defined whether and by what mechanism(s) $\mathrm{DS} / \mathrm{Cu}$ would be active against adult B-lineage acute lymphoblastic leukemia (B-ALL). Here we report that $\mathrm{DS} / \mathrm{Cu}$ is significantly and selectively cytotoxic in vitro against human B-ALL cell lines and primary samples obtained from adults with B-ALL, particularly those carrying adverse prognostic genetic abnormalities (e.g., p16 deletion), as well as effective in vivo in B-ALL patient-derived xenografts, in association with activation of the intrinsic apoptotic pathway, at least in part, due to down-regulation of Bcl-2 and Bcl-xL.

\section{RESULTS}

\section{DS/Cu exhibits dose-dependent cytotoxicity in human B-lineage acute lymphoblastic leukemia cell lines}

First, we examined the cytotoxic effect of $\mathrm{DS} / \mathrm{Cu}$ on two human B-ALL cell lines (i.e., Nalm6 and REH) using the Cell Counting Kit-8 (CCK-8). As shown in Figure 1A, while treatment with $\mathrm{Cu}$ alone had no significant effect on cell proliferation (inhibition rate $=6.39 \pm 4.93 \%, t=-2.244$, $P=0.154$ vs untreated control; not shown), exposure to a series of the indicated concentrations of DS coupled with $0.5 \mu \mathrm{M} \mathrm{Cu}(\mathrm{DS} / \mathrm{Cu})$ for $24 \mathrm{hrs}$ significantly inhibited proliferation of Nalm6 cells in a dose-dependent manner $(P<0.05$ for each condition vs untreated control), with IC50 values of $0.18 \pm 0.08 \mu \mathrm{M}$. Analogous results were obtained in another B-ALL cell line, REH (Figure 1A; $P<0.05$ for each condition vs untreated control), with IC50 values of $0.243 \pm 0.256 \mu \mathrm{M}$.
We next examined whether DS with or without $\mathrm{Cu}$ induce apoptosis in B-ALL cell lines. To this end, after exposed to various indicated concentrations of DS in the presence or absence of $0.5 \mu \mathrm{M} \mathrm{Cu}$ for $24 \mathrm{hrs}$, flow cytometric analysis with Annexin V/PI double staining was performed to determine the percentage of apoptotic cells. In both Nalm6 and REH cells, $\mathrm{Cu}(0.5$ $\mu \mathrm{M})$ administrated alone was unable to induce apoptosis $(P>0.05$ vs untreated control; see below Figure 1D). However, whereas $\geq 0.1 \mu \mathrm{M}$ DS alone had significant effects, treatment with DS at different doses $(0.025,0.05$, $0.1,0.2 \mu \mathrm{M}$ ) in combination with $0.5 \mu \mathrm{M} \mathrm{Cu}$ for $24 \mathrm{hrs}$ resulted in significantly increased apoptosis in a dosedependent manner in Nalm6 cells (Figure 1B; $P<0.05$ for each DS dose, DS/Cu vs either untreated control or DS alone). Comparable phenomena were observed in REH cells (Figure 1C; $P<0.05$ for each DS dose, except 0.025 $\mu \mathrm{M}, \mathrm{DS} / \mathrm{Cu}$ vs untreated control or DS alone). In addition to marked increases in overall percentage of Annexin $\mathrm{V}^{+}$ apoptotic cells when compared DS/Cu with DS alone, representative flow cytometric data also demonstrated that whereas DS $(\geq 0.1 \mu \mathrm{M})$ by itself predominantly induced early apoptosis (Annexin $\mathrm{V}^{+} / \mathrm{PI}^{-}$, lower/right quadrant Q3; Figure 1D, top panels), co-treatment (24 hrs) with DS ( $\geq$ $0.05 \mu \mathrm{M})$ and $\mathrm{Cu}(0.5 \mu \mathrm{M})$ resulted in robust increases in both early and late apoptosis (Annexin $\mathrm{V}^{+} / \mathrm{PI}^{+}$, upper/ right quadrant Q2; Figure 1D, bottom panels). However, exposure to neither DS nor DS/Cu resulted in necrosis (Annexin $\mathrm{V}^{-} / \mathrm{PI}^{+}$, upper/left quadrant Q1). Taken together, these results indicate that whereas DS itself is active against B-ALL cell lines, combined administration with non-toxic concentrations of $\mathrm{Cu}$ (e.g., $0.5 \mu \mathrm{M}$ ) remarkably potentiates cytotoxicity of DS, primarily via induction of apoptosis in a dose-dependent manner.

\section{DS/Cu preferentially induces apoptosis of primary adult B-ALL cells, but not normal PBMCs}

We then tested activity of DS/Cu in primary samples (bone marrow mononuclear cells) obtained from adults with B-ALL. Clinical characteristics of these B-ALL patients are summarized in Table 1 (also see Supplemental Table S1 for details). Consistent with the anti-leukemia activity of $\mathrm{DS} / \mathrm{Cu}$ observed in B-ALL cell lines, cotreatment (24 hrs) with $\geq 0.05 \mu \mathrm{M}$ DS and $0.5 \mu \mathrm{M} \mathrm{Cu}$ resulted in significant increases in apoptosis of primary B-ALL cells $(P<0.001$ vs untreated control, $\mathrm{n}=32$; Figure $2 \mathrm{~A})$, although the responses varied among patients. Regardless of the marked differences in basal levels of spontaneous cell death among these primary samples, average net increases in percentage of apoptotic cells were $7.16 \% 20.14 \% 29.52 \% 36.01 \%$ for $0.025,0.05,0.10$ and $0.20 \mu \mathrm{M}$ DS in combination with $0.5 \mu \mathrm{M} \mathrm{Cu}$, respectively, while only $1.29 \%$ for $\mathrm{Cu}$ alone (Table 2 ). Of note, identical treatments with $\mathrm{DS} / \mathrm{Cu}$ displayed minimal toxic towards 
normal peripheral blood mononuclear cells (PBMCs) obtained from healthy donors of hematopoietic stem cell transplantation (HSCT, Figure 2B and Table 2). These findings argue that $\mathrm{DS} / \mathrm{Cu}$ might selectively eliminate B-ALL cells, while sparing normal hematopoietic cells, in consistence with low-toxicity of DS as a safe antialcoholism drug.

\section{Cytotoxicity of DS/Cu against primary B-ALL cells correlates to $\mathrm{p} 16$ deletion and $\mathrm{WBC}$ count at diagnosis in adults with B-ALL patients}

To examine whether the clinical features of adult B-ALL patients (Table 1 and Supplemental Table S1) would have any effects on anti-leukemia activity of
$\mathrm{DS} / \mathrm{Cu}$ against primary B-ALL cells, we analyzed the potential relationship between patients' characteristics and the percentage of apoptotic cells induced by a series of concentrations of DS in combination with $0.5 \mu \mathrm{M} \mathrm{Cu}$. According to the NCCN Guidelines Version 1.2015 Acute Lymphoblastic Leukemia, high risk is generally defined as having any of the following poor-risk cytogenetic factors: hypodiploidy ( $<44$ chromosomes); t(v;11q23) or MLL rearrangements; $\mathrm{t}(9 ; 22)$ or $\mathrm{BCR}-\mathrm{ABL}$ gene mutations; or complex karyotype ( $\geq 5$ chromosomal abnormalities), while the absence of all poor-risk factors is considered standard risk.

Of total 32 patients enrolled in this study, median age was 27.5 years (range, 15-61 years); 11 (34.4\%) were age $\geq 35$ years; median peripheral white blood cell
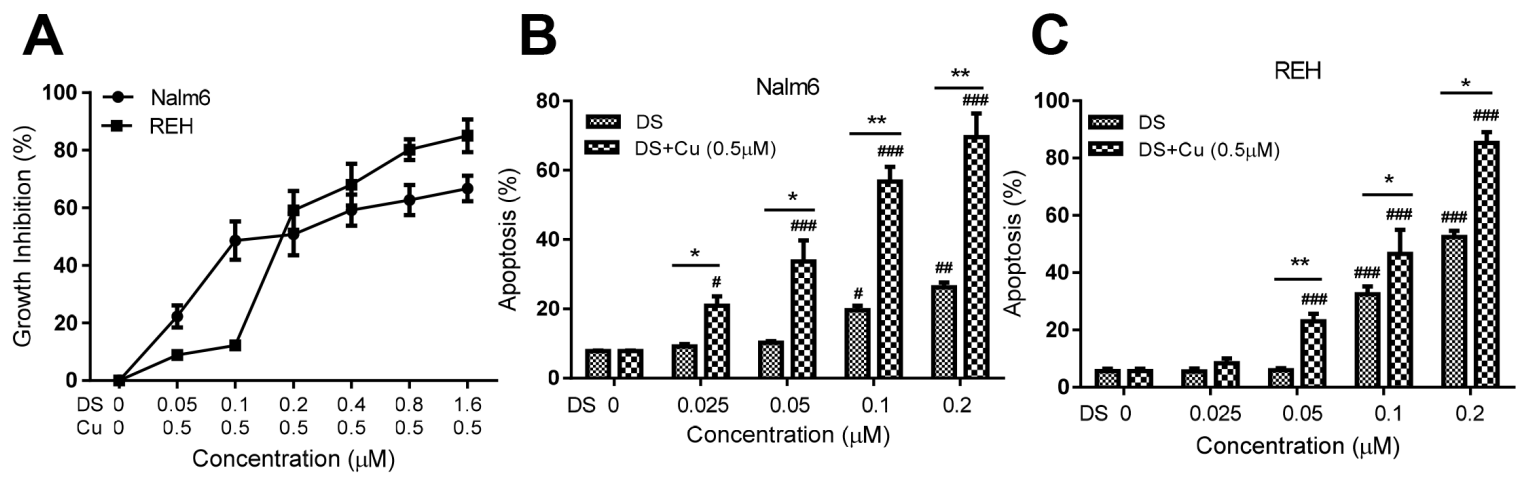

D

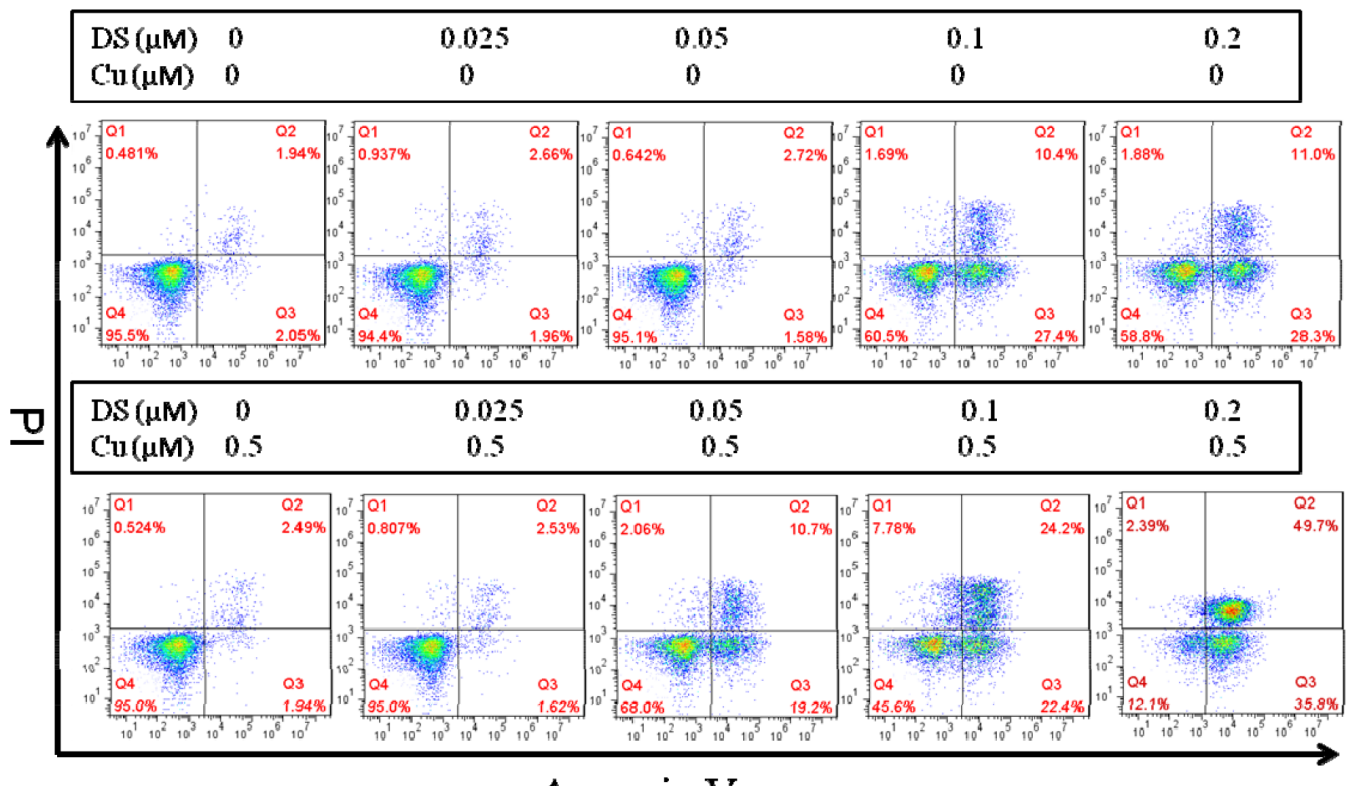

Annexin V

Figure 1: DS/Cu displays dose-dependent cytotoxic effects on human B-ALL Nalm6 and REH cells. A. Nalm6 and REH cells were exposed to the indicated concentrations of DS in the presence of $0.5 \mu \mathrm{M} \mathrm{Cu}$ for $24 \mathrm{hr}$, after which anti-proliferative effect was determined by a CCK-8 kit. B, C. Nalm6 (B) and REH cells (C) were treated with a series of concentrations of DS with or without 0.5 $\mu \mathrm{M} \mathrm{Cu}$ for $24 \mathrm{hr}$, after which percentage of apoptotic cells was determined by flow cytometry using Annexin V/PI double staining. ${ }^{\#}$ or $* P<0.05, \ldots$ or $* * P<0.01, \ldots \#$ or $* * * P<0.001$ vs untreated control or DS alone, respectively. D. Representative data for flow cytometric analysis of Annexin V/PI staining in Nalm6 cells after exposed ( $24 \mathrm{hr})$ to the indicated concentrations of DS with or without $\mathrm{Cu}(0.5 \mu \mathrm{M})$. 
Table 1: Patient clinical characteristics $(n=32)$

\begin{tabular}{|c|c|c|c|}
\hline Characteristic & Value & Number of patients & $\%$ \\
\hline \multicolumn{4}{|l|}{ Age, years } \\
\hline Median (range) & $27.5(15-61)$ & & \\
\hline$\geq 35$ & & 11 & 34.4 \\
\hline$<35$ & & 21 & 65.6 \\
\hline \multicolumn{4}{|l|}{$\mathrm{WBC}\left(\times 10^{9} / \mathrm{L}\right)$} \\
\hline Median (range) & $46.3(1.3-429.5)$ & & \\
\hline$\geq 30$ & & 22 & 68.8 \\
\hline$<30$ & & 10 & 31.2 \\
\hline \multicolumn{4}{|l|}{ LDH } \\
\hline High & & 22 & 68.8 \\
\hline Normal & & 10 & 34.4 \\
\hline \multicolumn{4}{|l|}{ Status of d14 } \\
\hline $\mathrm{CR}$ & & 20 & 62.5 \\
\hline NR & & 12 & 31.2 \\
\hline \multicolumn{4}{|c|}{ Status after induction therapy } \\
\hline $\mathrm{CR}$ & & 25 & 78.1 \\
\hline NR & & 7 & 21.9 \\
\hline \multicolumn{4}{|c|}{ Extramedullary infiltration } \\
\hline Yes & & 24 & 75 \\
\hline No & & 8 & 25 \\
\hline \multicolumn{4}{|l|}{ Immune phenotype } \\
\hline Pro-B & & 13 & 40.6 \\
\hline Non-proB & & 19 & 59.4 \\
\hline \multicolumn{4}{|l|}{ Risk category } \\
\hline High & & 13 & 40.6 \\
\hline Standard & & 19 & 59.4 \\
\hline \multicolumn{4}{|l|}{$\mathrm{Ph}$ chromosome } \\
\hline Positive & & 11 & 34.4 \\
\hline Negative & & 21 & 65.6 \\
\hline \multicolumn{4}{|l|}{ p16 gene deletion } \\
\hline Positive & & 12 & 42.9 \\
\hline Negative & & 16 & 57.1 \\
\hline
\end{tabular}

Abbreviations: WBC, white blood cell; LDH, lactic dehydrogenase; CR, complete remission; NR, No remission.

(WBC) count at diagnosis was $46.30 \times 10^{9} / \mathrm{L}$, (range, $\left.1.27-429.46 \times 10^{9} / \mathrm{L}\right)$; and $13(40.6 \%)$ and $19(59.4 \%)$ had high or standard risk diseases, respectively. As shown in Table 3, two-way ANOVA analysis revealed that the ex vivo efficacy of $\mathrm{DS} / \mathrm{Cu}$ towards primary B-ALL cells was significantly associated with WBC count at diagnosis $(P=0.044)$ and $\mathrm{p} 16$ gene deletion of patients $(P=0.008)$. However, other clinical characteristics (e.g., age, LDH levels, extramedullary infiltration, status at $14^{\text {th }}$ and $28^{\text {th }}$ day post intensive induction therapy, immune phenotype, 
risk category, $\mathrm{Ph}$ chromosome, etc.) did not significantly affect response of primary B-ALL cells to $\mathrm{DS} / \mathrm{Cu}(P>0.05$ for each of these parameters). These results raise a possibility that adults with B-ALL carrying certain adverse prognostic genetic abnormalities (e.g., p16 gene deletion) might be particularly susceptible to the $\mathrm{DS} / \mathrm{Cu}$ regimen.

\section{DS/Cu suppresses colony formation of B-ALL cells}

Clonogenic assays were carried out to investigate the ability of $\mathrm{DS} / \mathrm{Cu}$ to induce "reproductive death" in B-ALL cells. As shown in Figure 3, while treatment with $\mathrm{Cu}(0.5 \mu \mathrm{M})$ had no effect ( $P>0.05$ vs untreated control), treatment $(6 \mathrm{hrs})$ with DS $(0.05 \mu \mathrm{M})$ alone markedly reduced colony number in Nalm6 cells $(P<0.01$ vs untreated control). Of note, combined treatment with DS and $\mathrm{Cu}$ ( $6 \mathrm{hr}$ prior to plating) almost completely abolished the colony-forming ability of Nalm6 cells after cultured for 10-14 days $(P<0.01$ and $P<0.05$ vs untreated control and DS alone, respectively). These results indicate that DS is able suppress clonogenicity of B-ALL cells, an event dramatically enhanced by co-administration of $\mathrm{Cu}$.

\section{$\mathrm{DS} / \mathrm{Cu}$ induces loss of mitochondrial membrane potential and activation of the intrinsic apoptotic pathway, in association with down-regulation of Bcl-2 and Bcl-xL}

To further investigate the mechanism of action for $\mathrm{DS} / \mathrm{Cu}$ to kill B-ALL cells, mitochondrial membrane potential $(\Delta \Psi \mathrm{m})$ was analyzed by flow cytometry using the $\Delta \Psi \mathrm{m}$ probe JC-1 in both cultured B-ALL cell lines and primary B-ALL cells. As shown in Figure 4, treatment with DS in combination with $\mathrm{Cu}(0.5 \mu \mathrm{M})$ significantly reduced JC-1 up-take by Nalm6 (Figure 4A) and REH cells (Figure $4 \mathrm{~B} ; P<0.05$ for $\mathrm{DS}$ at doses $\geq 0.05 \mu \mathrm{M}$, compared to untreated control, in both cell lines), of which representative data is shown in Figure $4 \mathrm{C}$, consistent with induction of apoptosis (Figure 1B and 1C). Significantly, exposure (12 hrs) to DS/Cu also dose-dependently induced loss of $\Delta \Psi \mathrm{m}$ in primary B-ALL cells (Figure 4D, $P<0.05$ for $\mathrm{DS}$ at doses $\geq 0.1 \mu \mathrm{M}$, compared to untreated control, $\mathrm{n}=6$ ), isolated from the adults with B-ALL as marked in Supplemental Table S1. Furthermore, Western blot analysis revealed that whereas DS alone ( $24 \mathrm{hrs}$ ) modestly down-regulated the anti-apoptotic proteins $\mathrm{Bcl}-2$ and Bcl-xL, these effects of DS was markedly enhanced in the presence of $\mathrm{Cu}$, accompanied by increased caspase- 3 cleavage (activation) and PARP degradation (Figure 4E). Together, these findings suggest that DS, particularly in combination with $\mathrm{Cu}$, acts to induce cell death of adult B-ALL cells primarily via activation of the intrinsic apoptotic pathway, at least in part, due to down-regulation of anti-apoptotic Bcl-2 family proteins (e.g., Bcl-2 and Bxl-xL).

\section{$\mathrm{DS} / \mathrm{Cu}$ is active in vivo in patient-derived xenograft (PDX) models of adult B-ALL}

Last, in vivo anti-leukemia efficacy of $\mathrm{DS} / \mathrm{Cu}$ was examined in patient-derived xenograft models of NODscid-IL2Rg-/- (NSI) mice, generated from the primary sample of an adult B-ALL patient with p16 deletion. $\mathrm{Cu}$ and DS were administered by oral gavage in the morning and afternoon respectively, from Monday to Friday for

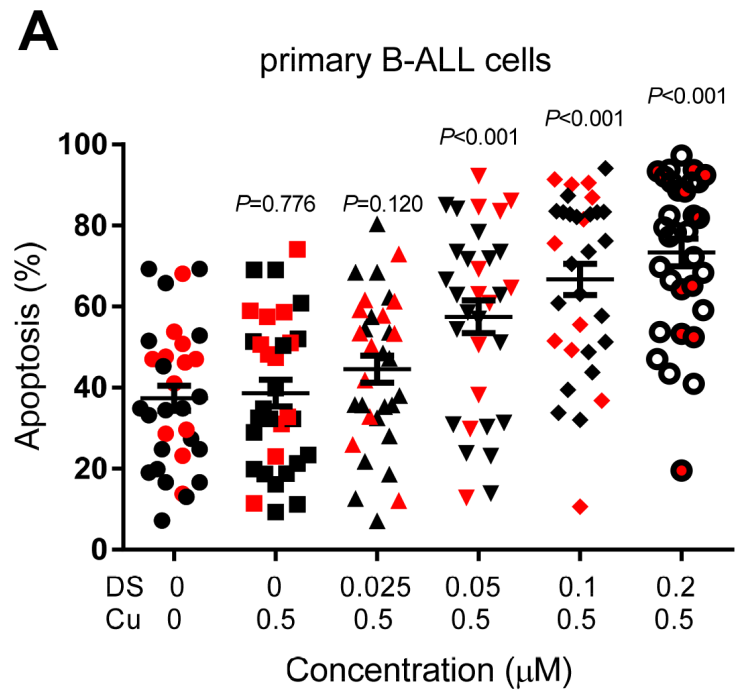

B

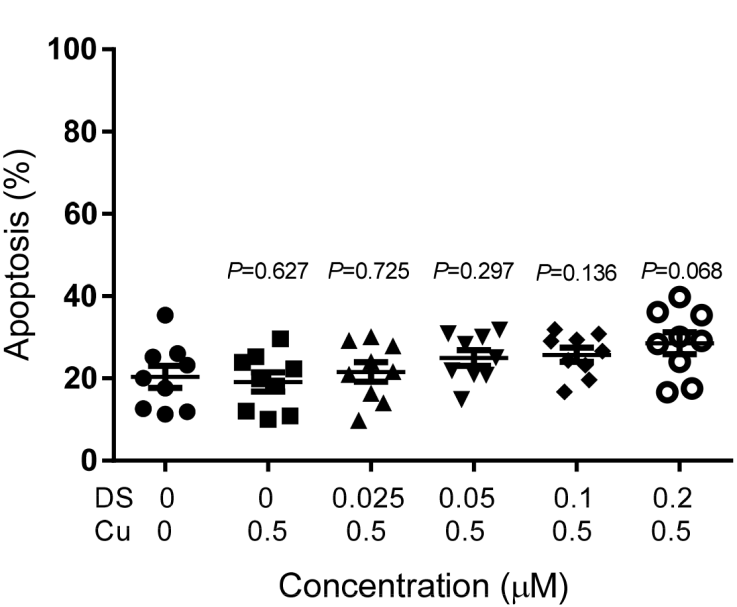

Figure 2: DS/Cu induces apoptosis in primary adult B-ALL cells but not normal PBMCs. A, B. mononuclear cells isolated from primary bone marrow of adults with B-ALL (A) and peripheral blood of healthy donors (B) were exposed to the indicated concentrations of DS with $0.5 \mathrm{mM} \mathrm{Cu}$ for $24 \mathrm{hr}$, after which flow cytometric analysis was performed to determine percentage of Annexin $\mathrm{V}^{+}$cells. The patients carrying p16 gene deletion are highlighted by red symbols. Horizontal lines represent the mean and SD of the values obtained from 32 patients (A) and 9 healthy donors (B). 
Table 2: Effects of DS treatment with or without Cu on human primary adult B-ALL cells (n=32) and normal PBMCs (n=9)

\begin{tabular}{lccccccc}
\hline DS $(\mu \mathrm{M})$ & 0 & 0 & 0.025 & 0.05 & 0.10 & 0.20 \\
$\mathrm{Cu}(\mu \mathrm{M})$ & 0 & 0.5 & 0.5 & 0.5 & 0.5 & 0.5 & $P$-value \\
\hline $\begin{array}{l}\text { Primary } \\
\text { B-ALL cells }\end{array}$ & $37.36 \pm 17.49$ & $38.65 \pm 18.68$ & $44.52 \pm 18.84$ & $57.50 \pm 22.87$ & $66.88 \pm 21.68$ & $73.37 \pm 19.20$ & 0.000 \\
Normal PBMCs & $19.57 \pm 7.40$ & $17.87 \pm 7.14$ & $20.89 \pm 8.22$ & $23.04 \pm 6.18$ & $24.76 \pm 6.57$ & $26.82 \pm 8.26$ & 0.117 \\
\hline
\end{tabular}

Primary B-ALL cells and normal PBMCs were incubated with the indicated doses of DS in the presence or absence of Cu for $24 \mathrm{hr}$, after which percentage of apoptotic cells were assessed by flow cytometry. Values represent mean \pm SD for at least three independent experiments.

Table 3: The relation between clinical characteristics of B-ALL patients and ex vivo cytotoxicity of DS/Cu in primary samples

\begin{tabular}{|c|c|c|c|c|c|c|c|c|}
\hline \multirow{2}{*}{ Characteristic } & $\mathrm{DS}(\mu \mathrm{M})$ & $\mathbf{0}$ & $\mathbf{0}$ & 0.025 & 0.05 & 0.10 & 0.20 & \multirow{2}{*}{$P$-value } \\
\hline & $\mathrm{Cu}(\boldsymbol{\mu} \mathrm{M})$ & $\mathbf{0}$ & 0.5 & 0.5 & 0.5 & 0.5 & 0.5 & \\
\hline \multirow{2}{*}{ Age, years } & $\geq 35(n=11)$ & $\begin{array}{c}37.36 \pm \\
17.91\end{array}$ & $\begin{array}{c}38.11 \pm \\
18.53\end{array}$ & $\begin{array}{c}45.47 \pm \\
19.96\end{array}$ & $\begin{array}{c}57.43 \pm \\
23.71\end{array}$ & $\begin{array}{c}65 \pm \\
23.59\end{array}$ & $\begin{array}{c}72.81 \pm \\
20.61\end{array}$ & \multirow{3}{*}{0.744} \\
\hline & $<35(\mathrm{n}=21)$ & $\begin{array}{c}37.35 \pm \\
17.49\end{array}$ & $\begin{array}{c}39.68 \pm \\
19.81\end{array}$ & $\begin{array}{c}42.71 \pm \\
17.26\end{array}$ & $\begin{array}{c}57.62 \pm \\
22.31\end{array}$ & $\begin{array}{c}69.88 \pm \\
18.09\end{array}$ & $\begin{array}{c}74.44 \pm \\
17.06\end{array}$ & \\
\hline \multirow{2}{*}{$\mathrm{WBC}\left(\times 10^{9} / \mathrm{L}\right)$} & $\geq 30(n=22)$ & $\begin{array}{c}40.04 \pm \\
19.37\end{array}$ & $\begin{array}{c}41.96 \pm \\
20.28\end{array}$ & $\begin{array}{c}48.88 \pm \\
18.27\end{array}$ & $\begin{array}{c}62.57 \pm \\
21.65\end{array}$ & $\begin{array}{c}69.26 \pm \\
21.59\end{array}$ & $\begin{array}{c}73.88 \pm \\
19.09\end{array}$ & \\
\hline & $<30(\mathrm{n}=10)$ & $\begin{array}{c}32.82 \pm \\
11.31\end{array}$ & $\begin{array}{c}35.48 \pm \\
14.53\end{array}$ & $\begin{array}{c}39.55 \pm \\
16.84\end{array}$ & $\begin{array}{c}51.46 \pm \\
24.1\end{array}$ & $\begin{array}{c}61.88 \pm \\
22.32\end{array}$ & $\begin{array}{c}69.09 \pm \\
18.83\end{array}$ & $0.044^{*}$ \\
\hline \multirow{2}{*}{$\mathrm{LDH}$} & $\operatorname{High}(n=22)$ & $\begin{array}{c}38.80 \pm \\
18.95\end{array}$ & $\begin{array}{c}40.52 \pm \\
19.92\end{array}$ & $\begin{array}{c}44.67 \pm \\
22.28\end{array}$ & $\begin{array}{c}55.83 \pm \\
25.61\end{array}$ & $\begin{array}{c}64.37 \pm \\
23.25\end{array}$ & $\begin{array}{c}71.77 \pm \\
20.82\end{array}$ & \multirow{3}{*}{0.644} \\
\hline & $\operatorname{Normal}(n=10)$ & $\begin{array}{c}34.61 \pm \\
15.85\end{array}$ & $\begin{array}{c}36.13 \pm \\
17.63\end{array}$ & $\begin{array}{c}48.62 \pm \\
14.92\end{array}$ & $\begin{array}{l}62.6 \pm \\
16.43\end{array}$ & $\begin{array}{c}71.96 \pm \\
18.04\end{array}$ & $\begin{array}{c}76.02 \pm \\
15.26\end{array}$ & \\
\hline \multirow{2}{*}{ Status of d14 } & $\mathrm{CR}(\mathrm{n}=20)$ & $\begin{array}{c}37.17 \pm \\
17.7\end{array}$ & $\begin{array}{c}38.91 \pm \\
18.66\end{array}$ & $\begin{array}{c}45.97 \pm \\
18.15\end{array}$ & $\begin{array}{l}56.3 \pm \\
23.19\end{array}$ & $\begin{array}{c}63.92 \pm \\
20.85\end{array}$ & $\begin{array}{c}71.80 \pm \\
17.4\end{array}$ & \\
\hline & $\mathrm{NR}(\mathrm{n}=12)$ & $\begin{array}{l}36.7 \pm \\
19.76\end{array}$ & $\begin{array}{c}38.41 \pm \\
21.32\end{array}$ & $\begin{array}{c}42.71 \pm \\
21.97\end{array}$ & $\begin{array}{c}57.39 \pm \\
25.91\end{array}$ & $\begin{array}{c}69.62 \pm \\
23.23\end{array}$ & $\begin{array}{c}74.32 \pm \\
21.83\end{array}$ & 0.577 \\
\hline \multirow{2}{*}{$\begin{array}{l}\text { Status after } \\
\text { induction } \\
\text { therapy }\end{array}$} & $\mathrm{CR}(\mathrm{n}=25)$ & $\begin{array}{c}40.42 \pm \\
17.46\end{array}$ & $\begin{array}{c}39.88 \pm \\
17.98\end{array}$ & $\begin{array}{c}46.83 \pm \\
17.52\end{array}$ & $\begin{array}{c}59.63 \pm \\
22.7\end{array}$ & $\begin{array}{c}67.43 \pm \\
20.67\end{array}$ & $\begin{array}{c}73.94 \pm \\
18.35\end{array}$ & \multirow{3}{*}{0.106} \\
\hline & $N R(n=7)$ & $\begin{array}{c}33.86 \pm \\
21.82\end{array}$ & $\begin{array}{c}35.95 \pm \\
24.92\end{array}$ & $\begin{array}{c}38.55 \pm \\
24.63\end{array}$ & $\begin{array}{l}50.6 \pm \\
25.48\end{array}$ & $\begin{array}{c}63.76 \pm \\
28.04\end{array}$ & $\begin{array}{c}69.52 \pm \\
23.8\end{array}$ & \\
\hline \multirow{2}{*}{$\begin{array}{l}\text { Extramedullary } \\
\text { infiltration }\end{array}$} & $\operatorname{yes}(n=24)$ & $\begin{array}{c}37.42 \pm \\
16.94\end{array}$ & $\begin{array}{c}38.89 \pm \\
17.84\end{array}$ & $\begin{array}{c}42.24 \pm \\
18.73\end{array}$ & $\begin{array}{c}55.95 \pm \\
21.15\end{array}$ & $\begin{array}{c}65.73 \pm \\
22.72\end{array}$ & $\begin{array}{c}73.42 \pm \\
20.39\end{array}$ & \\
\hline & $\operatorname{No}(n=8)$ & $\begin{array}{l}37.7 \pm \\
21.79\end{array}$ & $\begin{array}{c}39.91 \pm \\
23.69\end{array}$ & $\begin{array}{c}54.41 \pm \\
17.26\end{array}$ & $\begin{array}{c}63.89 \pm \\
15.05\end{array}$ & $\begin{array}{c}69.78 \pm \\
19.68\end{array}$ & $\begin{array}{c}72.13 \pm \\
15.78\end{array}$ & 0.542 \\
\hline
\end{tabular}

(Continued) 


\begin{tabular}{|c|c|c|c|c|c|c|c|c|}
\hline \multirow{2}{*}{ Characteristic } & $\mathrm{DS}(\boldsymbol{\mu M})$ & $\mathbf{0}$ & $\mathbf{0}$ & 0.025 & 0.05 & 0.10 & 0.20 & \multirow{2}{*}{$P$-value } \\
\hline & $\mathrm{Cu}(\boldsymbol{\mu} \mathrm{M})$ & $\mathbf{0}$ & 0.5 & 0.5 & 0.5 & 0.5 & 0.5 & \\
\hline \multirow{2}{*}{$\begin{array}{l}\text { Immune } \\
\text { phenotype }\end{array}$} & Pro-B $(n=13)$ & $\begin{array}{c}36.35 \pm \\
19.94\end{array}$ & $\begin{array}{c}37.46 \pm \\
20.5\end{array}$ & $\begin{array}{c}45.34 \pm \\
17.69\end{array}$ & $\begin{array}{c}62.97 \pm \\
17.7\end{array}$ & $\begin{array}{c}71.11 \pm \\
16.46\end{array}$ & $\begin{array}{c}75.58 \pm \\
13.25\end{array}$ & \multirow{3}{*}{0.484} \\
\hline & $\begin{array}{c}\text { Non- } \\
\operatorname{proB}(n=19)\end{array}$ & $\begin{array}{c}38.28 \pm \\
16.86\end{array}$ & $\begin{array}{c}40.30 \pm \\
18.49\end{array}$ & $\begin{array}{c}45.24 \pm \\
20.12\end{array}$ & $\begin{array}{c}54.49 \pm \\
26.04\end{array}$ & $\begin{array}{c}63.75 \pm \\
24.73\end{array}$ & $\begin{array}{l}71.4 \pm \\
22.46\end{array}$ & \\
\hline \multirow{2}{*}{ Risk category } & $\operatorname{High}(n=13)$ & $\begin{array}{c}39.25 \pm \\
19.75\end{array}$ & $\begin{array}{c}42.03 \pm \\
20.95\end{array}$ & $\begin{array}{c}45.21 \pm \\
19.13\end{array}$ & $\begin{array}{l}58.6 \pm \\
19.06\end{array}$ & $\begin{array}{c}69.34 \pm \\
18.59\end{array}$ & $\begin{array}{c}75.11 \pm \\
17.13\end{array}$ & \\
\hline & Standard $(n=19)$ & $\begin{array}{c}36.29 \pm \\
16.96\end{array}$ & $\begin{array}{c}37.17 \pm \\
17.97\end{array}$ & $\begin{array}{c}45.32 \pm \\
19.22\end{array}$ & $\begin{array}{c}57.44 \pm \\
26.05\end{array}$ & $\begin{array}{c}65.08 \pm \\
23.75\end{array}$ & $\begin{array}{c}71.28 \pm \\
22.03\end{array}$ & 0.341 \\
\hline \multirow{2}{*}{$\begin{array}{l}\mathrm{Ph} \\
\text { chromosome }\end{array}$} & $\operatorname{Positive}(\mathrm{n}=11)$ & $\begin{array}{c}41.18 \pm \\
20.94\end{array}$ & $\begin{array}{c}44.19 \pm \\
21.86\end{array}$ & $\begin{array}{c}44.53 \pm \\
19.95\end{array}$ & $\begin{array}{c}55.84 \pm \\
19.27\end{array}$ & $\begin{array}{c}66.39 \pm \\
18.74\end{array}$ & $\begin{array}{c}72.48 \pm \\
17.39\end{array}$ & \multirow{3}{*}{0.994} \\
\hline & $\operatorname{Negative}(n=21)$ & $\begin{array}{c}35.56 \pm \\
16.3\end{array}$ & $\begin{array}{c}36.51 \pm \\
17.4\end{array}$ & $\begin{array}{c}45.67 \pm \\
18.77\end{array}$ & $\begin{array}{c}59.03 \pm \\
25.23\end{array}$ & $\begin{array}{c}66.93 \pm \\
23.63\end{array}$ & $\begin{array}{c}73.44 \pm \\
20.39\end{array}$ & \\
\hline \multirow{2}{*}{$\begin{array}{l}\text { p16 gene } \\
\text { deletion }\end{array}$} & $\operatorname{Positive}(\mathrm{n}=12)$ & $\begin{array}{c}41.41 \pm \\
15.02\end{array}$ & $\begin{array}{c}45.39 \pm \\
17.63\end{array}$ & $\begin{array}{c}48.56 \pm \\
17.34\end{array}$ & $\begin{array}{c}61.28 \pm \\
24.65\end{array}$ & $\begin{array}{c}67.27 \pm \\
26.21\end{array}$ & $\begin{array}{c}73.71 \pm \\
22.52\end{array}$ & \\
\hline & Negative $(n=16)$ & $\begin{array}{c}30.09 \pm \\
16.49\end{array}$ & $\begin{array}{c}30.37 \pm \\
16.57\end{array}$ & $\begin{array}{c}38.08 \pm \\
18.07\end{array}$ & $\begin{array}{c}52.57 \pm \\
23.43\end{array}$ & $\begin{array}{c}65.06 \pm \\
20.38\end{array}$ & $\begin{array}{c}72.04 \pm \\
18.69\end{array}$ & $0.008 * *$ \\
\hline
\end{tabular}

Primary B-ALL cells were exposed to the indicated concentrations of DS with or without $\mathrm{Cu}$ for 24hr, after which percentage of apoptotic cells were determined by flow cytometry. Values represent mean \pm SD of at least three independent experiments. $* P<0.05, * * P<0.01$.
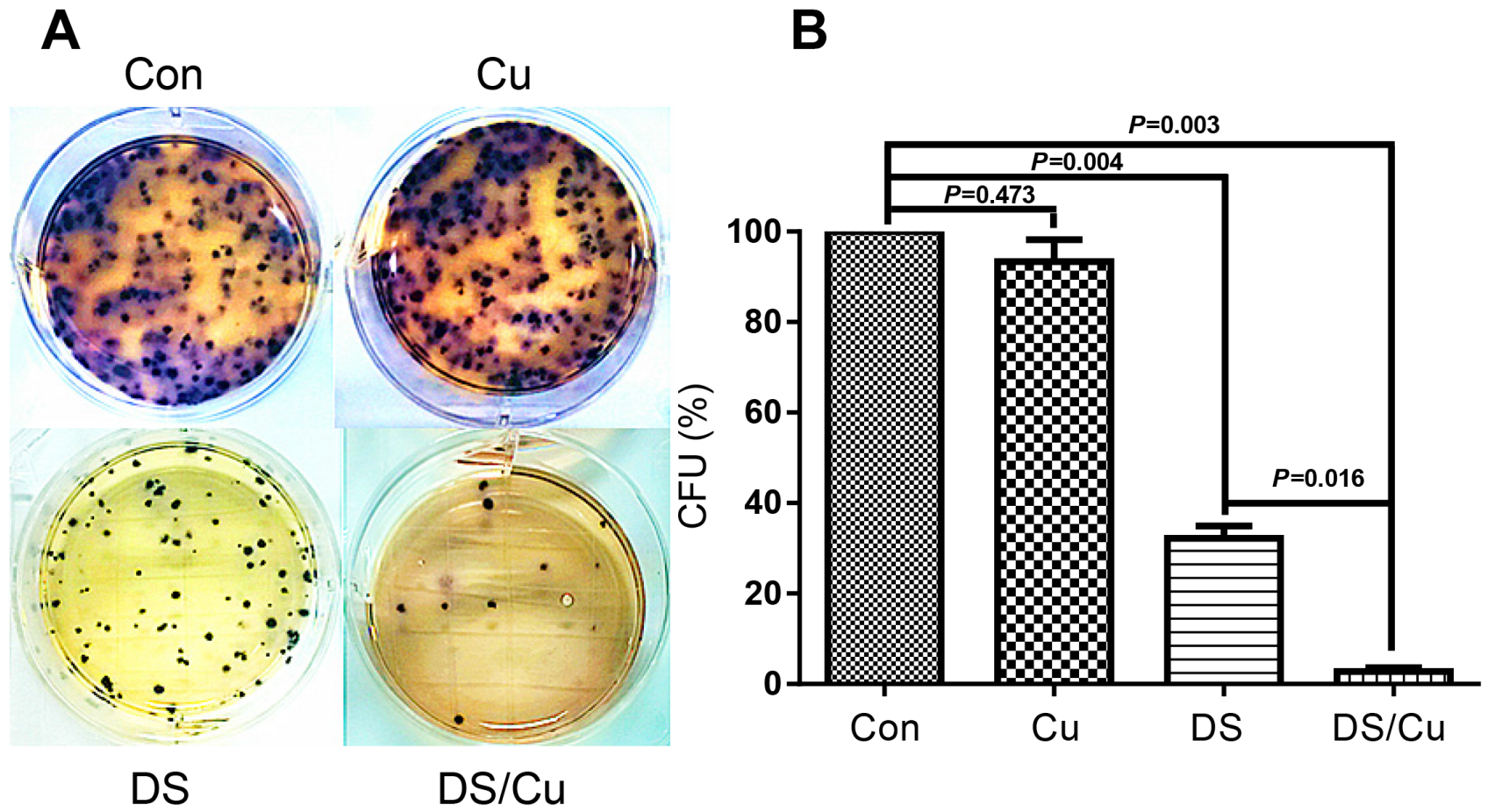

Figure 3: DS/Cu significantly abolishes the colony-forming ability of Nalm6 cells. A. Nalm6 cells were exposed to $0.05 \mu \mathrm{M}$ DS with or without $0.5 \mu \mathrm{M} \mathrm{Cu}$ for $6 \mathrm{hr}$, after which clonogeic assay was performed as described in Methods. B. Percentage of colonyforming units $(\mathrm{CFU})$ was determined by counting colonies ( $\geq 50$ cells). Values represent the mean $\pm \mathrm{SD}$ for at least three independent experiments. 
consecutive 4 weeks. Notably, mice received $\mathrm{DS} / \mathrm{Cu}$ displayed a substantial delay in tumor growth, manifested by appearance of human $\mathrm{CD} 45^{+}$cells in peripheral blood (PB) determined by flow cytometry in none of 5 mice, while 4 of 5 mice developed $\mathrm{CD}_{4} 5^{+}$lesions in the control group, after 5 weeks of transplantation (Figure 5A). Consistently, co-administration of $\mathrm{DS} / \mathrm{Cu}$ remarkably reduced tumor burden in the B-ALL PDX models, reflected by significantly less human $\mathrm{CD}_{4} 5^{+}$cells in bone marrow (BM, Figure 5B) and spleen (SP, Figure 5C) compared to control mice $(P<0.001$ for each case). Moreover, average weight (upper panel, $0.054 \pm 0.018$ $\mathrm{g}$ for the $\mathrm{DS} / \mathrm{Cu}$ group vs $0.276 \pm 0.078 \mathrm{~g}$ for control group, $P=0.002$ ) and size (lower panel) of spleens in mice received $\mathrm{DS} / \mathrm{Cu}$ treatment were markedly lower or smaller than those of control mice. Representative data for detection of human $\mathrm{CD} 45^{+}$cells in $\mathrm{PB}, \mathrm{BM}$, and $\mathrm{SP}$ of PDX mice was shown in Figure 5E. Furthermore,
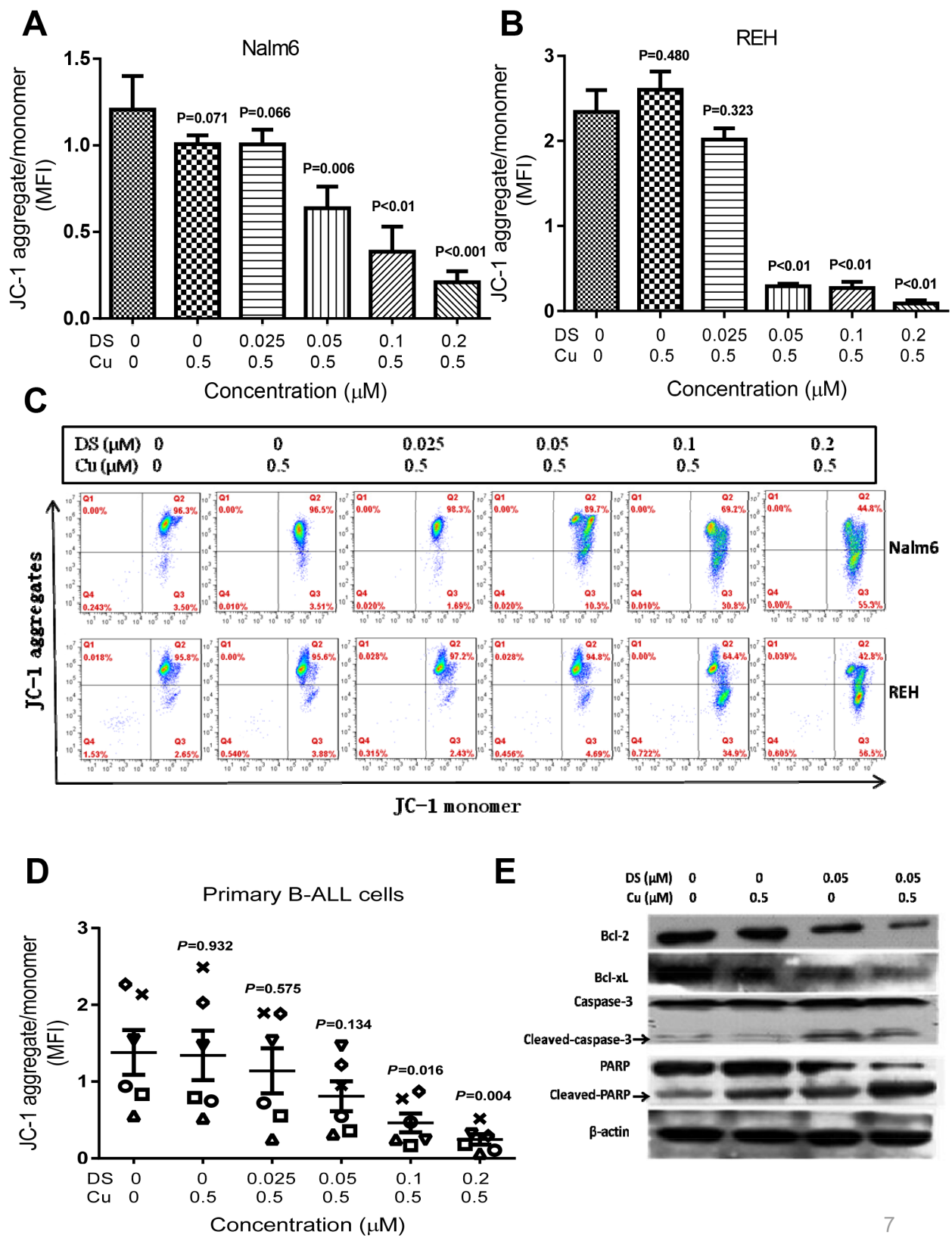

Figure 4: DS/Cu activates the mitochondria-related intrinsic apoptotic pathway in B-ALL cell lines and primary cells. A-D. Nalm6 (A and C, upper panels), REH (B and C, lower panels), and primary B-ALL cells ( $\mathrm{D}, \mathrm{n}=6)$ were exposed to the indicated doses of DS with $0.5 \mu \mathrm{M} \mathrm{Cu}$ for $12 \mathrm{hr}$, after which mitochondrial membrane potential was measured by flow cytometry using a JC-1 kit as per the manufacturer's instruction. MFI, mean fluorescence intensity. E. Nalm6 cells were incubated with $0.05 \mu \mathrm{M} \mathrm{DS}+/-0.5 \mu \mathrm{M}$ Cu for $24 \mathrm{hr}$, followed by Western blot analysis to monitor expression of Bcl-2 and Bcl-xL, as well as cleavage of caspase 3 and PARP. 
A

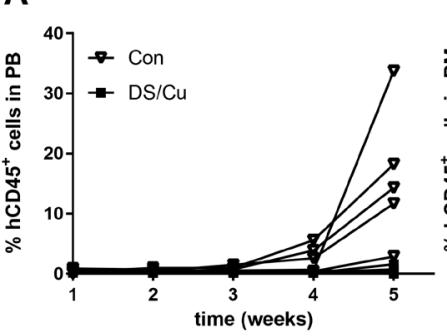

C
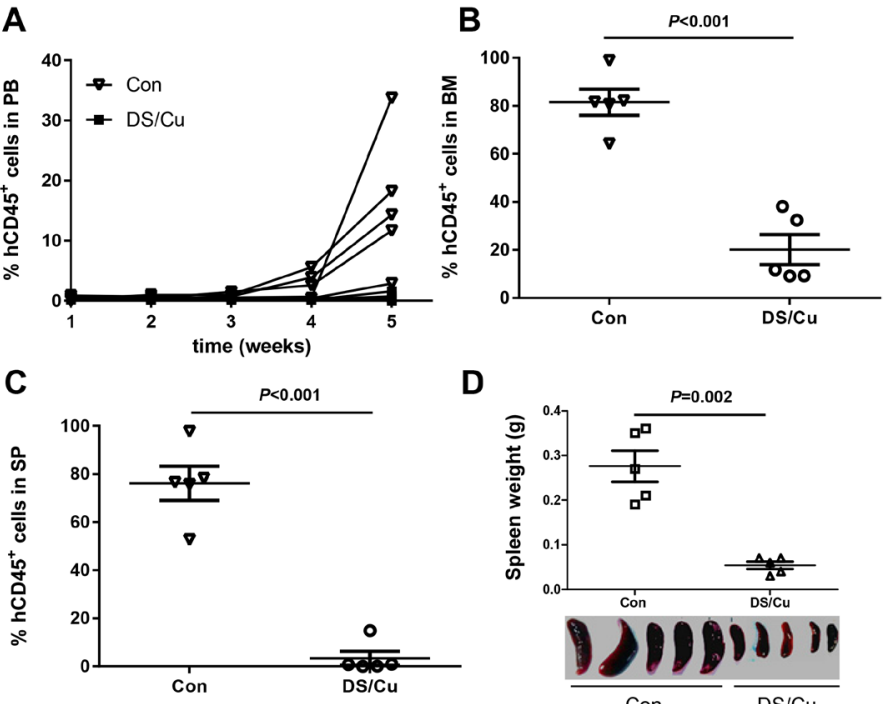

D

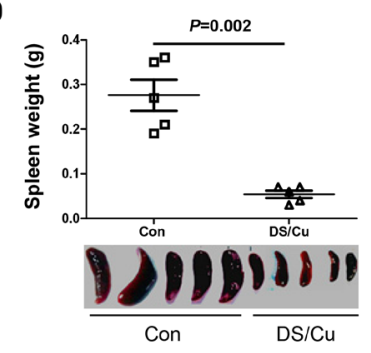

$E$

PB

BM


G

$\mathrm{DS} / \mathrm{Cu}$

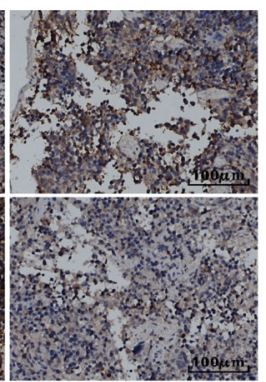

Figure 5: DS/Cu is active in vivo in patient-derived xenograft model of adult B-ALL. A-C. Primary cells $\left(1 \times 10^{6}\right.$ mononuclear cells per mouse) isolated from an adult with B-ALL were intravenously injected via retro-orbital vein into NSI mice. 7 days after cell inoculation, mice were randomized ( $\mathrm{n}=5$ per group) and treated with vehicle (control group) or $\mathrm{DS} / \mathrm{Cu}$ (administered by oral gavage at dose of $1.5 \mathrm{mg} / \mathrm{kg} \mathrm{Cu}$ in the morning and $150 \mathrm{mg} / \mathrm{kg}$ DS in the afternoon, from Monday to Friday for consecutive 4 weeks). Percentage of human $\mathrm{CD}^{+} 5^{+}$(hCD45) cells in peripheral blood (PB, A), bone marrow (BM, B) and spleen (SP, C) were then determined by flow cytometry. D. Spleens of mice were weighted and photographed at the end of the study (5 weeks after cells inoculation). E. Representative data of flow cytometry for detection of human $\mathrm{CD}^{+} 5^{+}$cells in PB, BM, and SP. F. Paraffin-embedded sections of spleen, bone marrow, lung, kidney, and liver were stained with H\&E. G. Histologic sections of bone marrow were stained for human Bcl-2 and Bcl-xL by immunohistochemistry (IHC). Scale bar, $100 \mu \mathrm{m}$. 
histopathology after 5 weeks following transplantation revealed a remarkable reduction in infiltration of leukemic cells, accompanied by well preserved normal tissue architecture, in the spleen, bone marrow, lung, liver, and kidney of the PDX mice receiving $\mathrm{DS} / \mathrm{Cu}$, compared to control mice (Figure 5F). Finally, immunohistochemistry (IHC) staining demonstrated that treatment with $\mathrm{DS} / \mathrm{Cu}$ clearly down-regulated the expression of Bcl-2 and Bcl-xL in bone marrow of the PDX mice (Figure 5G), consistent with the in vitro observation that $\mathrm{DS} / \mathrm{Cu}$ activated the intrinsic apoptotic pathway (Figure 4E). Together, these findings argue strongly that the $\mathrm{DS} / \mathrm{Cu}$ regimen is highly active in vivo in adult B-ALL PDX models.

\section{DISCUSSION}

Evidence has been emerging on identifying new uses for existing drugs, termed repurposing or repositioning, as an accelerated way for drug development. Repositioning existing drugs could increase productivity of drug development by shortening the process from laboratory investigation to clinical application due to their easy availability and known safety or toxicity profile. DS, also known as Antabuse, has been approved by the Food and Drug Administration (FDA) for the treatment of alcohol abuse and dependence (alcoholism) for more than six decades. Recently, repositioning DS for new indications has attracted a lot of attention in treatment of cancer. The anti-cancer activity of DS, particularly in a form of coupling with $\mathrm{Cu}(\mathrm{DS} / \mathrm{Cu})$, has been demonstrated in a variety of cancers. For example, Conticello et al. have reported that primary cells isolated from patients with various hematological malignancies, including multiple myeloma (MM), acute myeloid (AML) and lymphoblastic leukemia (ALL), were significantly sensitive to DS alone or in combination with $\mathrm{Cu}$ [19]. Consistently, the present studies have further validated the anti-leukemia activity of $\mathrm{DS} / \mathrm{Cu}$ in vitro in B-ALL cell lines and especially in primary samples obtained adults with B-ALL. Of note, in vivo efficacy of $\mathrm{DS} / \mathrm{Cu}$ was identified, to the best of our knowledge, for the first time in PDX models generated from tumor cells derived from an adult B-ALL patient.

In this pre-clinical setting, $\mathrm{DS} / \mathrm{Cu}$ exhibited remarkable cytotoxicity against both B-ALL cell lines and primary adult B-ALL cells, while was only minimally toxic towards normal PBMCs obtained from healthy HSCT donors and cord blood, suggesting that the DS/Cu regimen might be able to potently and selectively eliminate adult B-ALL cells. The IC50 of DS in combination with $\mathrm{Cu}(0.5 \mu \mathrm{M})$ for inhibiting proliferation of Nalm6 and REH cells was $0.18 \mu \mathrm{M}$ and $0.24 \mu \mathrm{M}$, respectively, which are lower than the DS IC50 of $0.5 \mu \mathrm{M}$ in a mixture with $\mathrm{Cu}$ in $\mathrm{MM}$ cell lines [19]. It is noteworthy that the anti-proliferative IC50 of $0.5 \mu \mathrm{M}$ for both DS and $\mathrm{Cu}$ is significantly lower than the concentration achieved with a normal adult dose for the treatment of alcoholism and for $\mathrm{Cu}$ recommended dietary intake [19]. Thus, the doses of DS and $\mathrm{Cu}$ that were effective against B-ALL cells fall within these low- or non-toxic dose range of these agents. Indeed, while exposure to $0.05-0.2 \mu \mathrm{M}$ DS with $0.5 \mu \mathrm{M} \mathrm{Cu}$ was highly active to induce apoptosis in both B-ALL cell lines and primary adult B-ALL cells in a dosedependent manner, treatment with the identical doses (i.e., $\leq 0.2 \mu \mathrm{M}$ ) of DS with $0.5 \mu \mathrm{M} \mathrm{Cu}$ displayed only minor toxicity towards normal cells. Moreover, whereas DS administrated alone had clear effects on B-ALL cells, combined treatment with non-toxic doses of $\mathrm{Cu}$ (e.g., $0.5 \mu \mathrm{M})$ dramatically enhanced activity of DS, including markedly increased induction of apoptosis and suppression of colony formation in B-ALL cells. Moreover, the latter also provides evidence for the capability of $\mathrm{DS} / \mathrm{Cu}$ to impair clonogenicity of B-ALL cells. Notably, DS/Cu was also highly active in vivo in PDX models of adult B-ALL, which were developed using humanized NSI mouse [25, 26], including substantial delay of tumor growth, reduction of tumor burden, and attenuation of leukemic cell infiltration in multiple organs (e.g., spleen, bone marrow, lung, liver, and kidney). Taken together, these in vitro and in vivo findings argue strongly that DS, especially when administrated in combination with $\mathrm{Cu}$, might represent an effective repurposing regimen for the treatment of adult B-ALL.

It is well established that the therapeutic response and prognosis of patients with ALL are significantly influenced by multiple risk factors, including age, WBC count at the time of first diagnosis, extramedullary infiltration, cytogenetic abnormalities, etc. [27-31] Moreover, high-risk diseases are associated with greater incidence of chemo-resistance, higher rate of relapse, and lower rate of survival. To this end, we further analyzed the relationship between clinical characteristics and antitumor activity of $\mathrm{DS} / \mathrm{Cu}$ in their primary samples obtained from 32 adults with B-ALL. Interestingly, we found that the ex vivo cytotoxicity of $\mathrm{DS} / \mathrm{Cu}$ was significantly associated with peripheral WBC count at diagnosis and p16 gene deletion, but not other clinical features such as age, LDH value, extramedullary infiltration, status at day 14 and 28 after intensive induction therapy, immune phenotype, risk category, and $\mathrm{Ph}$ chromosome. While the mechanisms underlying such correlations between therapeutic responses to $\mathrm{DS} / \mathrm{Cu}$ and $\mathrm{WBC}$ counts or p16 deletion remain to be explored in successor studies, these findings might provide initial evidence for future development of the $\mathrm{DS} / \mathrm{Cu}$ regimen as personalized treatment of adult B-ALL.

Several mechanisms have been reported for induction of apoptosis by DS/Cu in cancer cells, including production of reactive oxygen species [10], inhibition of proteasome activity [11], regulation of transcription factors (e.g., NF- $\mathrm{B}$ ), and activation of the stress-related JNK signaling pathway $[17,18]$. It has also been demonstrated that $\mathrm{DS} / \mathrm{Cu}$ cytotoxicity may attribute to modulation of the 
anti- and pro-apoptotic Bcl-2 family proteins in human glioblastoma cells, as well as ALDH-positive cancer stem-like cells [10] and breast cancer stem cells [12]. The results of the present study elucidate that $\mathrm{DS} / \mathrm{Cu}$ induced apoptosis of B-ALL cells most likely via activation of the mitochondria-related intrinsic apoptotic pathway, reflected by loss of mitochondria membrane potential, downregulation of anti-apoptotic Bcl-2 family proteins (e.g., Bcl-2 and Bcl-xL), and following caspase-3 activation and PARP degradation. A similar mechanism for anti-leukemia activity of $\mathrm{DS} / \mathrm{Cu}$ might also operate in vivo in PDX models of adult B-ALL, manifested by down-regulation of Bcl-2 and Bcl-xL after co-administration of $\mathrm{DS} / \mathrm{Cu}$. While the mechanisms underlying down-regulation of these anti-apoptotic proteins by $\mathrm{DS} / \mathrm{Cu}$ remains to be defined, the results of the present study suggest that $\mathrm{DS} / \mathrm{Cu}$ might primarily act to activate the mitochondria-mediated intrinsic apoptotic pathway, at least in part, via downregulation of the anti-apoptotic Bcl-2 family proteins (e.g., Bcl-2 and Bcl-xL).

In summary, the present study demonstrated that DS in combination with $\mathrm{Cu}$ effectively and selectively eradicates adult B-ALL cells, including inhibition of tumor cell proliferation, induction of apoptosis, impair of clonogenicity, and suppression of tumor growth in PDX models. Significantly, cytotoxicity of DS/Cu correlated to certain clinical adverse prognostic factors including WBC counts at diagnosis and p16 gene deletion. Moreover, anti-leukemia activity of $\mathrm{DS} / \mathrm{Cu}$ was mechanistically associated with down-regulation of the anti-apoptotic Bcl-2 family members and activation of the mitochondriamediated intrinsic apoptotic pathway. Therefore, the present findings suggest that the DS/Cu regimen warrants further consideration in adult B-ALL, particularly certain clinical/genetic subsets with poor prognosis.

\section{MATERIALS AND METHODS}

\section{Chemicals and reagents}

Disulfiram (Santa Cruz Biotechnology Inc., Santa Cruz, CA, USA) and copper (Sigma-Aldrich, Dorset, UK) were dissolved in DMSO as $5 \mathrm{mM}$ stock solution and phosphate-buffered saline (PBS) as $100 \mathrm{mM}$ stock solution, respectively. Both stock solutions were stored at $-20^{\circ} \mathrm{C}$ and freshly diluted with culture medium before use.

\section{Cell lines and cell culture}

Nalm6 and REH cell lines were purchased from ATCC (Teddington, UK). Cells were cultured in RPMI1640 (HyClone, Thermo Scientific, Waltham, MA, USA) supplemented with $10 \%$ fetal bovine serum (FBS, Gibco, Life Technologies, NY, USA), $100 \mathrm{U} / \mathrm{ml}$ penicillin and $100 \mu \mathrm{g} / \mathrm{ml}$ streptomycin $(1 \times \mathrm{P} / \mathrm{S})$.

\section{Primary samples}

Peripheral blood (PB) samples from healthy hematopoietic stem cell transplantation (HSCT) donors and bone marrow (BM) samples from newly diagnosed adult B-ALL patients were obtained at Department of Hematology, Nanfang Hospital, Southern Medical University. Informed consent was provided for research purposes only, approved by the Nanfang Hospital Ethics Review Board, in accordance with the Declaration of Helsinki. Clinical characteristics of the B-ALL patients are summarized in Table 1 and Supplemental Table S1. Mononuclear cells were isolated by density gradient centrifugation using Lymphoprep ${ }^{\mathrm{TM}}$ (BD, Franklin Lakes, NJ, USA), washed twice with PBS, and cultured in IMDM (HyClone, Thermo Scientific) supplemented with 10\% FBS (Gibco, Life Technologies), $100 \mathrm{U} / \mathrm{ml}$ penicillin and $100 \mu \mathrm{g} / \mathrm{ml}$ streptomycin $(1 \times \mathrm{P} / \mathrm{S})$.

\section{Cell counting kit-8 (CCK-8) assay}

Cytotoxicity of $\mathrm{DS} / \mathrm{Cu}$ was determined using a CCK-8 kit (Dojindo, Kumamoto, Japan). Briefly, cells $\left(5 \times 10^{4}\right.$ cells/well) were plated into 96 -well plates containing $100 \mu \mathrm{l}$ of growth medium and then treated with designated doses of DS in combination with $0.5 \mu \mathrm{M}$ $\mathrm{Cu}$ for $24 \mathrm{hrs}$. After treatment, CCK-8 reagents $(10 \mu \mathrm{l} /$ well) were added and incubated for $2 \mathrm{hrs}$ at $37^{\circ} \mathrm{C}$ in a $5 \%$ $\mathrm{CO}_{2}$ incubator. Finally, absorbance at $450 \mathrm{~nm}$ were read by a microplate reader (ELX800, Bio TEK, USA). All experiments were repeated three times and performed in triplicate in each experiment. The $\mathrm{IC}_{50}$ value of each cell line was calculated using GraphPad Prism 5.

\section{Annexin V-APC/PI double staining assay by flow cytometry}

Apoptosis was measured using Annexin V-APC/ PI (Ebioscience, San Diego, USA) dual staining by flow cytometry. Briefly, cells $\left(2 \times 10^{5} /\right.$ well $)$ were seeded into $24-$ well plates and exposed to DS at different doses $(0.025$, $0.05,0.1,0.2 \mu \mathrm{M})$ either with or without $\mathrm{Cu}(0.5 \mu \mathrm{M})$ for 24 hrs. Cells were harvested, washed twice with iced PBS, and double labeled with Annexin V-APC/PI for 30 minutes at $4^{\circ} \mathrm{C}$ in the dark. Cells were then analyzed by flow cytometry using FACS C6 (BD, Oxford, UK).

\section{Clonogenic assay}

Cells $\left(2 \times 10^{5} /\right.$ well $)$ were seeded in 24 -well plates and treated for $6 \mathrm{hrs}$ with DS $(0.05 \mu \mathrm{M})$ alone or in combination with $\mathrm{Cu}(0.5 \mu \mathrm{M})$. Cells were collected and further cultured in complete methylcellulose medium at a cell density of 500/well in 6-well plates for 14 days. Colonies consisting of at least 50 cells were counted and analyzed for clonogenicity. 


\section{Analysis of mitochondrial membrane potential}

Mitochondrial membrane potential (MMP, $\Delta \Psi \mathrm{m}$ ) was determined using a JC-1 kit (Beyotime Biotechnology, China) as per the manufacturer's instruction. After exposed to various concentrations of DS in combination with $0.5 \mu \mathrm{M} \mathrm{Cu}$ for $12 \mathrm{hrs}$, cells were collected, washed twice with iced PBS, resuspended in $500 \mu 11 \times$ working JC-1 solution, and incubated for $20 \mathrm{~min}$ at $37^{\circ} \mathrm{C}$ in the dark. After washing twice with a JC-1 buffer solution, MMP were analyzed by FACS C6 (BD).

\section{Western blot analysis}

Whole cell lysates $(30 \mu \mathrm{g}$ protein/lane) was electrophoresed in $10 \%$ SDS- PAGE and transferred to a PVDF membrane (Millipore, Billerica, MA, USA). After blocked for $1 \mathrm{hr}$ for non-specific binding in TBS-T with 5\% non-fat milk, blots were incubated with primary antibodies (Bcl-2, rabbit polyclonal, 1:500; PARP, rabbit polyclonal, 1:500; Bcl-xL, rabbit polyclonal, 1:1000, Cell Signaling Technology, Inc. Herts, UK; caspase-3, rabbit monoclonal, 1:1000, Beyotime, China) overnight at $4^{\circ} \mathrm{C}$, followed by secondary HRP-conjugated monoclonal antibody (1:10000, Cell Signaling Technology) for $1 \mathrm{~h}$ at room temperature. Blots were re-probed with $\beta$-actin antibody (rabbit-monoclonal, 1:1000, Cell Signaling Technology) to ensure equal protein loading. Blots were visualized on X-ray films using an enhanced chemiluminescence Western blotting detection kit (Amersham, Little Chalfont, UK).

\section{Animal studies in patient-derived xenograft (PDX) models}

Male NSI 6 to 8 week old mice $[25,26]$ were kindly provided by Dr. Peng Li (Guangzhou Institutes of Biomedicine and Health, Chinese Academy of Sciences, Guangzhou, China) and housed under pathogen-free conditions according to the animal care guidelines. The protocols for the animal studies were approved by Southern Medical University. On the day of tumor cell inoculation, mice received 1 Gy of total body irradiation at a dose rate of $325 \mathrm{cGy} / \mathrm{min}$ by parallel opposed $4 \mathrm{MV}$ x-ray. Within $24 \mathrm{hrs}$, mice were intravenously injected via retro-orbital vein with $1 \times 10^{6}$ primary mononuclear cells isolated from adults with B-ALL. Seven days after transplantation of patient B-ALL cells, mice were randomly assigned to either control or $\mathrm{DS} / \mathrm{Cu}$ group ( $=5$ per group) and then treated respectively with either vehicle (PBS and $0.5 \%$ methyl cellulose $/ 0.5 \%$ Tween 80 in PBS) or $1.5 \mathrm{mg} / \mathrm{kg} / \mathrm{d} \mathrm{Cu}$ in the morning followed by $150 \mathrm{mg} / \mathrm{kg} / \mathrm{d} \mathrm{DS}$ in the afternoon by oral gavage from Monday to Friday for 4 consecutive weeks. Tumor burden of mice was monitored every 7 days by flow cytometry after staining peripheral blood (PB, 50-100 $\mu \mathrm{L}$ ) collected from retro-orbital vein with an anti-humanCD45 antibody. At the end of the experiments, mice were euthanized, after which their spleens were photographed and weighed, and leukemia load (human $\mathrm{CD}^{+} 5^{+}$cells) in peripheral blood (PB), bone marrow (BM) and spleen was determined by flow cytometry after staining with antihuman-CD45 antibody. The viscera organs (including $\mathrm{BM}$, spleen, liver and kidney) were removed and fixed in $10 \%$ paraformaldehyde for $24 \mathrm{hrs}$, after which paraffinembedded sections were prepared and subjected to H\&E staining and immunohistochemistry (IHC) for human Bcl2 and Bcl-xL.

\section{Statistical analysis}

Values represent the mean $\pm \mathrm{SD}$ for at least three independent experiments. Comparisons between two groups were analyzed using the 2-tailed Student's t test. Multiple-group comparisons were performed using the One-way analysis of variance (ANOVA) followed by the Bonferroni posthoc test. Two-way ANOVA analysis was used to examine the relationship between various clinical characteristics of B-ALL patients and cytotoxicity of DS/ $\mathrm{Cu}$ against primary B-ALL cells. Analyses utilized IBM SPSS 19.0 and GraphPad Prism 5.0 software. $P$ values $<$ 0.05 was considered as statistically significant.

\section{ACKNOWLEDGMENTS}

This work was supported by the National Natural Science Foundation of China (No. 81428003, No. 81400104, and No. 81570156).

\section{CONFLICTS OF INTEREST}

The authors declare no potential conflicts of interest.

\section{REFERENCES}

1. Faderl S, Jeha S, Kantarjian HM. The biology and therapy of adult acute lymphoblastic leukemia. Cancer. 2003; 98:1337-1354

2. Graux C. Biology of acute lymphoblastic leukemia (ALL): clinical and therapeutic relevance. Transfus Apher Sci. 2011; 44:183-189.

3. Narayanan S, Shami PJ. Treatment of acute lymphoblastic leukemia in adults. Crit Rev Oncol Hematol. 2012; 81:94-102.

4. Ai J, Advani A. Current status of antibody therapy in ALL. Br J Haematol. 2015; 168:471-480.

5. Bassan R, Hoelzer D. Modern therapy of acute lymphoblastic leukemia. J Clin Oncol. 2011; 29:532-543.

6. Cvek B. Targeting malignancies with disulfiram (Antabuse): multidrug resistance, angiogenesis, and proteasome. Curr Cancer Drug Targets. 2011; 11:332-337.

7. Johansson B. A review of the pharmacokinetics and pharmacodynamics of disulfiram and its metabolites. Acta Psychiatr Scand Suppl. 1992; 369:15-26. 
8. Cen D, Brayton D, Shahandeh B, Meyskens FJ, Farmer PJ. Disulfiram facilitates intracellular $\mathrm{Cu}$ uptake and induces apoptosis in human melanoma cells. J Med Chem. 2004; 47:6914-6920.

9. Morrison BW, Doudican NA, Patel KR, Orlow SJ. Disulfiram induces copper-dependent stimulation of reactive oxygen species and activation of the extrinsic apoptotic pathway in melanoma. Melanoma Res. 2010; 20:11-20.

10. Liu P, Brown S, Goktug T, Channathodiyil P, Kannappan V, Hugnot JP, Guichet PO, Bian X, Armesilla AL, Darling JL, Wang W. Cytotoxic effect of disulfiram/copper on human glioblastoma cell lines and ALDH-positive cancerstem-like cells. Br J Cancer. 2012; 107:1488-1497.

11. Chen D, Cui QC, Yang H, Dou QP. Disulfiram, a clinically used anti-alcoholism drug and copper-binding agent, induces apoptotic cell death in breast cancer cultures and xenografts via inhibition of the proteasome activity. Cancer Res. 2006; 66:10425-10433.

12. Yip NC, Fombon IS, Liu P, Brown S, Kannappan V, Armesilla AL, Xu B, Cassidy J, Darling JL, Wang W. Disulfiram modulated ROS-MAPK and NFkappaB pathways and targeted breast cancer cells with cancer stem cell-like properties. Br J Cancer. 2011; 104:1564-1574.

13. Zhang H, Chen D, Ringler J, Chen W, Cui QC, Ethier SP, Dou QP, Wu G. Disulfiram treatment facilitates phosphoinositide 3-kinase inhibition in human breast cancer cells in vitro and in vivo. Cancer Res. 2010; 70:3996-4004.

14. Brar SS, Grigg C, Wilson KS, Holder WJ, Dreau D, Austin C, Foster M, Ghio AJ, Whorton AR, Stowell GW, Whittall LB, Whittle RR, White DP, Kennedy TP. Disulfiram inhibits activating transcription factor/cyclic AMP-responsive element binding protein and human melanoma growth in a metal-dependent manner in vitro, in mice and in a patient with metastatic disease. Mol Cancer Ther. 2004; 3:1049-1060.

15. Cen D, Brayton D, Shahandeh B, Meyskens FJ, Farmer PJ. Disulfiram facilitates intracellular $\mathrm{Cu}$ uptake and induces apoptosis in human melanoma cells. J Med Chem. 2004; 47:6914-6920.

16. Lin J, Haffner MC, Zhang Y, Lee BH, Brennen WN, Britton J, Kachhap SK, Shim JS, Liu JO, Nelson WG, Yegnasubramanian S, Carducci MA. Disulfiram is a DNA demethylating agent and inhibits prostate cancer cell growth. Prostate. 2011; 71:333-343.

17. Zha J, Chen F, Dong H, Shi P, Yao Y, Zhang Y, Li R, Wang S, Li P, Wang W, Xu B. Disulfiram targeting lymphoid malignant cell lines via ROS-JNK activation as well as Nrf2 and NF-kB pathway inhibition. J Transl Med. 2014; 12:163.

18. Xu B, Shi P, Fombon IS, Zhang Y, Huang F, Wang W, Zhou S. Disulfiram/copper complex activated JNK/c-jun pathway and sensitized cytotoxicity of doxorubicin in doxorubicin resistant leukemia HL60 cells. Blood Cells Mol Dis. 2011; 47:264-269.

19. Conticello C, Martinetti D, Adamo L, Buccheri S, Giuffrida R, Parrinello N, Lombardo L, Anastasi G, Amato G, Cavalli
M, Chiarenza A, De Maria R, Giustolisi R, Gulisano M, Di Raimondo F. Disulfiram, an old drug with new potential therapeutic uses for human hematological malignancies. Int J Cancer. 2012; 131:2197-2203.

20. Elmore S. Apoptosis: A Review of Programmed Cell Death. Toxicol Pathol. 2007; 35:495-516.

21. Ouyang L, Shi Z, Zhao S, Wang FT, Zhou TT, Liu B, Bao JK. Programmed cell death pathways in cancer: a review of apoptosis, autophagy and programmed necrosis. Cell Prolif. 2012; 45:487-498.

22. Jeong SY, Seol DW. The role of mitochondria in apoptosis. BMB Rep. 2008; 41:11-22.

23. Granville DJ, Gottlieb RA. Mitochondria: regulators of cell death and survival. ScientificWorldJournal. 2002; 2:1569-1578.

24. Gupta S, Kass GE, Szegezdi E, Joseph B. The mitochondrial death pathway: a promising therapeutic target in diseases. $\mathrm{J}$ Cell Mol Med. 2009; 13:1004-1033.

25. Ye W, Jiang Z, Li GX, Xiao Y, Lin S, Lai Y, Wang S, Li B, Jia B, Li Y, Huang ZL, Li J, Feng F, Li S, Yao H, Liu $Z$, et al. Quantitative evaluation of the immunodeficiency of a mouse strain by tumor engraftments. J Hematol Oncol. 2015; 8:59.

26. Xiao Y, Jiang Z, Li Y, Ye W, Jia B, Zhang M, Xu Y, Wu D, Lai L, Chen Y, Chang Y, Huang X, Liu H, Qing G, Liu P, Li Y, et al. ANGPTL7 regulates the expansion and repopulation of human hematopoietic stem and progenitor cells. Haematologica. 2015; 100:585-594.

27. Hoelzer D, Thiel E, Loffler H, Buchner T, Ganser A, Heil G, Koch P, Freund M, Diedrich H, Ruhl H, Et A. Prognostic factors in a multicenter study for treatment of acute lymphoblastic leukemia in adults. Blood. 1988; 71:123-131.

28. Kantarjian H, Thomas D, O'Brien S, Cortes J, Giles F, Jeha S, Bueso-Ramos CE, Pierce S, Shan J, Koller C, Beran M, Keating M, Freireich EJ. Long-term follow-up results of hyperfractionated cyclophosphamide, vincristine, doxorubicin, and dexamethasone (Hyper-CVAD), a doseintensive regimen, in adult acute lymphocytic leukemia. Cancer. 2004; 101:2788-2801.

29. Rowe JM, Buck G, Burnett AK, Chopra R, Wiernik PH, Richards SM, Lazarus HM, Franklin IM, Litzow MR, Ciobanu N, Prentice HG, Durrant J, Tallman MS, Goldstone $\mathrm{AH}$. Induction therapy for adults with acute lymphoblastic leukemia: results of more than 1500 patients from the international ALL trial: MRC UKALL XII/ECOG E2993. Blood. 2005; 106:3760-3767.

30. Le QH, Thomas X, Ecochard R, Iwaz J, Lheritier V, Michallet M, Fiere D. Initial and late prognostic factors to predict survival in adult acute lymphoblastic leukaemia. Eur J Haematol. 2006; 77:471-479.

31. Mrozek K, Harper DP, Aplan PD. Cytogenetics and molecular genetics of acute lymphoblastic leukemia. Hematol Oncol Clin North Am. 2009; 23:991-1010. 